\title{
Introduction. Minority families and the law: Interactions of ethnic, religious, and cultural minorities with law and state institutions
}

OÑATI SOCIO-LEGAL SERIES VOLUME 11, ISSUE 4 (2021), 948-958: MINORITY FAMILIES AND THE LAW: INTERACTIONS OF ETHNIC, RELIGIOUS, AND CULTURAL MINORITIES WITH LAW AND STATE INSTITUTIONS DOI LINK: HTTPS://DOI.ORG/10.35295/OSLS.IISL/0000-0000-0000-1210

RECEIVED 14 JULY 2021, ACCEPTED 15 JULY 2021

\section{IRIS SPORTEL* (iD)}

\section{Abstract}

The state is an important presence in the lives of many minority families. This special issue aims to investigate the interactions of minority families with law and state institutions from a socio-legal perspective, with a particular focus on issues relating to children. This introduction focuses on two observations. First of all, minority families tend to get into contact with law and state institutions relatively often. For migrant and transnational families, migration law can have a large and enduring impact on many aspects of their lives. Furthermore, marginalisation of minorities and differences in decision-making by state actors can contribute to an overrepresentation of minority families in state interventions such as the child protection or criminal justice systems. Secondly some minority families tend to avoid state law and institutions. Especially in family matters such as marriage or divorce, minority family members may look for alternative options outside of the state, concluding religious marriages or divorces.

\section{Key words}

Encounters with the state; migration law; avoiding the law

\section{Resumen}

El Estado es una presencia importante en las vidas de muchas familias de minorías. Este número especial pretende investigar las interacciones de las familias de minorías con las leyes y las instituciones estatales desde una perspectiva socio-jurídica,

\footnotetext{
* Iris Sportel is an Assistant Professor at the Institute for Sociology of Law and the Centre for Migration Law of Radboud University Nijmegen, the Netherlands. She holds a PhD (2014) in sociology of law and gender studies from Radboud University. As a legal anthropologist, her research focusses on how individual actors - ordinary people, legal professionals, and parties in court procedures - deal with and experience law and legal institutions, especially in contexts of migration and transnationalism. She wrote Transnational Families and Divorce, Marriage, Migration, and Family Law (Palgrave Macmillan, 2016). Currently, she is working on a research project on Religion, culture, and ethnicity in court procedures on children from minority families, financed by a VENI grant from the Netherlands Organisation for Scientific Research (NWO). Email address: iris.sportel@ru.nl
} 
con especial atención a los temas relacionados con niños. Esta introducción se centra en dos observaciones. En primer lugar, las familias de minorías tienden a entrar en contacto con las leyes y las instituciones estatales con relativa frecuencia. Para familias migrantes y transnacionales, la marginalización de las minorías y las diferencias en la toma de decisiones de agentes estatales puede contribuir a una sobrerrepresentación de las familias de minorías en intervenciones estatales como la prostitución infantil o los sistemas de justicia penal. En segundo lugar, algunas familias de minorías tienden a eludir las leyes y las instituciones estatales. Especialmente en asuntos familiares como el matrimonio y el divorcio, los miembros de familias de minorías pueden buscar opciones alternativas fuera del Estado, como matrimonios y divorcios religiosos.

\section{Palabras clave}

Encuentros con el Estado; ley de migraciones; eludir la ley 


\section{Table of contents}

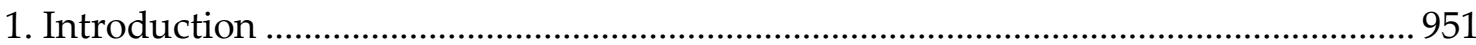

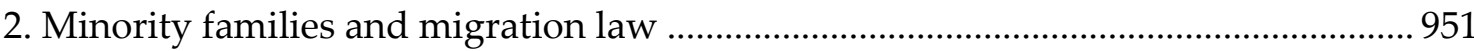

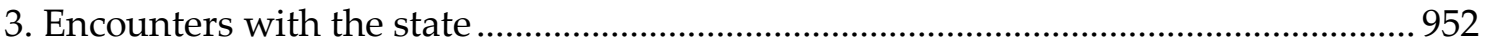

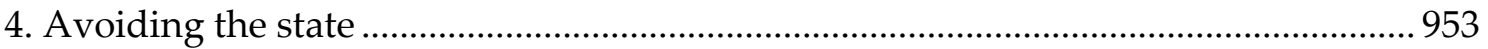

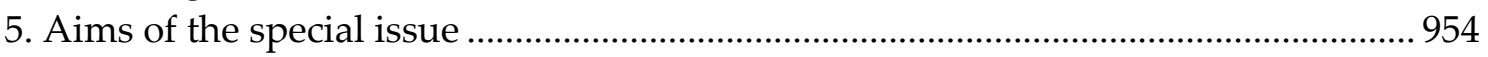

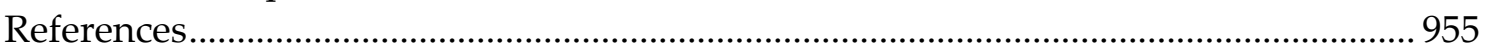




\section{Introduction}

In the last decennia, European families have become increasingly diverse. This diversity has posed challenges to policymakers and state institutions. This special issue aims to investigate the interactions of minority families with law and state institutions from a socio-legal perspective, with a particular focus on issues relating to children. The state is an important presence in the lives of many minority families, particularly migrants and transnational families. The state categorises people, demands obligations, gives rights, and provides services (Feldman-Savelsberg 2016). The religious, cultural, or ethnic identity of children can play a role in a wide range of contexts, including education; child welfare and protection systems; migration and naturalisation services; family law matters; as well as in the courts. This special issue is the result of a workshop at the Oñati International Institute for the Sociology of Law in 2019, entitled Minority families and the law. Interactions of ethnic, religious, and cultural minorities with law and state institutions. All of the contributions in this special issue were presented at this workshop.

This introduction will depart from two observations, based on a comparative reading of the contributions. First of all, minority families tend get into contact with law and state institutions relatively often. Specifically for migrant and transnational families, migration law can have a large and enduring impact on many aspects of their lives. Furthermore, marginalisation of minorities as well as differences in decision-making by state actors can contribute to an overrepresentation of minority families in state interventions such as the child protection and criminal law systems. Secondly, possibly as a consequence of this first observation, some minority families tend to avoid state law and institutions. Especially in family matters such as marriage or divorce, minority family members may look for alternative options outside of the state, such as religious marriages or divorces.

\section{Minority families and migration law}

Migration law status has an impact on many aspects of the lives of migrants and transnational families, as well as on their interactions with the state, for example with regard to welfare, housing, education, and the ability to share life with family members. Particularly for those living with precarious legal statuses, living in reception centres, or relying on the state for welfare, "the law is all over" (Sarat 1990). From research on migration and asylum procedures it is clear that such procedures can have a large and enduring impact on the lives of migrants and their families, especially when people have been involved in prolonged and contentious legal procedures or have been living with irregular or precarious legal statuses (Coutin 2003, Charsley 2005, Gleeson 2010, Abrego 2011, Kubal 2014, Shinozaki 2015, Menjívar and Lakhani 2016, Feldman-Savelsberg 2017, Sportel 2016, Sportel et al. 2019, Andrikopoulos 2021, de Hart and Besselsen 2021, Griffiths 2021). Alqawasmi's contribution to this special issue also shows the importance of a migration law status for future dealings with the state. For people without valid residence permits or papers, it was often not possible to conduct a civil marriage in Italy, which was one of the reasons Muslims in Alqawasmi's study opted for a religious marriage at an Islamic centre.

In this special issue, Hiitola's contribution demonstrates the profound impact migration law has on young forced migrants living in Finland. Most of the young people she 
interviewed came as unaccompanied minors to Finland. Strict Finnish family reunification policies meant that for many of them it was impossible to bring family members to the country. Living separately from family members and worrying for their safety abroad had a large impact on the young migrants' wellbeing. The young people Hiitola interviewed had a strong wish to be independent and to provide for their transnational family members, at an age where many young people in Europe still depend on their parents. Hiitola links this strong sense of wanting to be independent to these young people's experiences of dependency on the state, due to living in state systems as minors as well as the lack of control over migration procedures. Hiitola uses the concept of "everyday security" to shed light on the material, interpersonal, and existential (in)securities these young forced migrants experience. Although migration regimes made it impossible for most young migrants to live in the same country as their family, transnational family ties and even memories of family life were an important source of security in their lives.

In Mustasaari's contribution on ISIS-families, the ability of the state to control who enters and lives in its territories is also paramount. While the women and children at the centre of the debates she analysed are Finnish nationals, and therefore not subject to migration law, their imprisonment in the Al-Hol camp in Syria means they cannot return to Finland without the agreement and aid of the state.

\section{Encounters with the state}

Marginalised minorities are more like to come into contact with state institutions, for example with regard to welfare, housing, child protection, education, healthcare, or the criminal justice system (Malheiros 2002, Vinnerljung et al. 2008, Walker 2008, Blom et al. 2016, Petintseva 2018, Webster 2018, Leerkes et al. 2019). These encounters with the state (Jones 2012) can be characterised by processes of inclusion and exclusion, in which issues like securitisation (Ragazzi 2016), belonging (Mustasaari 2021, this special issue), or discrimination can play a role. In Mustasaari's contribution to this special issue, she analyses the role of affective constructions of justice in the Finnish public debates on ISIS-families. Mustasaari suggests there is a "connection between the way in which the women and children in Al-Hol are depicted as undeserving of basic fundamental rights and the process through which ethnic minority families in Finland become further ethnicized and racialized" (Mustasaari 2021, this special issue, p. 1041). Building on the work of Yuval-Davis, Wemyss, and Cassidy (2019) on bordering as an affective practice, Mustasaari shows how, despite being Finnish and white, in these debates the ISISfamilies are excluded from belonging to the Finnish nation and are recast as foreign and dangerous subjects.

Fresnoza-Flot's contribution on Filipino mothers and divorce analyses how these mothers deal with law and state institutions concerning their children during divorce. Fresnoza-Flot states that separating mixed couples with children are more exposed to socio-legal challenges during divorce processes compared to their counterparts in nonmixed families. This "also implies the inevitability of the encounters of these couples with legal institutions or entities and the intersectionality of divorce's implications on their lives." (Fresnoza-Flot 2021, this special issue, p. 995). The transnational dimension of the encounters with state institutions sets these Filipino mothers apart from mothers in non-mixed divorced families. Fresnoza-Flot also found that mothers with younger 
children as well as with more conflictual divorces had more encounters with state institutions. At the same time, however, some mothers avoided interacting with state institutions or claiming rights. This will be further discussed below.

My own contribution to this special issue deals with ethnic, religious, or cultural claims made by minority family members in court cases against state institutions in the Netherlands. In the literature on courts and minority families, such claims are often discussed in the context of the so-called cultural defence, where perpetrators of crimes make cultural claims to avoid or lessen punishment. However, as I show in this contribution, family members do not just make such claims to defend themselves. They can also demand exceptions of state policies, accommodation of particular practices, or to challenge discrimination by state institutions. By analysing claims-making as a performative practice of persuasion (Zivi 2011) I show how Dutch courts are often reluctant to engage with such claims, and tend to leave them out of court judgements entirely. I argue that this lack of engagement - or downright dismissal - should be understood in the context of general Dutch discourses of colour-blindness and of assimilation and integration of migrant minorities.

\section{Avoiding the state}

While marginalised and migrant minorities tend to have more contact with state institutions, at the same time - and possibly as a consequence of these involuntary encounters with the state - some minority families tend to avoid state law and institutions such as the courts. There is a rich literature on alternative dispute resolution by minority groups, especially in contexts of migration and post-colonialism. A substantial part of this literature focuses on Muslim minorities in the UK (for example: Bano 2007, 2012, Keshavjee 2007, Tas 2013, Akhtar 2013, Bowen 2016, Jones 2020), and to a lesser extent in other European countries such as the Netherlands, Germany, and the Nordic countries (van Rossum 1999, Al-Sharmani 2017, Rohe 2018, Jaraba 2020). Religious or culturally-based conflict-resolution outside of the state is often viewed with suspicion by European state actors, as well as in public debates, especially when it considers Muslim minorities (Jones and Shanneik, 2020). For example, in the past decade, several European countries have commissioned research to investigate "parallel justice" practices of Muslims, such as in the UK (Siddiqui et al. 2018); the Netherlands (Bakker et al. 2010); and Germany (Rohe and Jaraba 2015).

However, as the contributions to this special issue show, there are many different reasons for minority family members to arrange family matters outside of state institutions. As Alqawasmi found in her research on Islamic centres in Italy, Muslim institutions lack an agreement with the state as other denominations in Italy have. This means that if Muslims in Italy want a legally valid marriage, they need to conduct a civil marriage, which can be followed by a religious marriage at an Islamic centre. Different from other religious groups, there is no option to conclude a state-sanctioned, religiously valid marriage. As Alqawasmi found, some couples choose to conduct religious marriages without a civil marriage. Such informal marriages are not necessarily motivated by cultural or religious reasons. For example, as some people in Alqawasmi's study did not have a valid residence permit or the necessary papers to conduct a civil marriage, they turned to the Islamic centres to get married. As Alqawasmi points out, conducting a religious marriage without a civil marriage also means that there are no 
options to resort to state courts to divorce or to claim maintenance or property rights if the marriage breaks down, which means mediation by religious centres might be their only option for dispute resolution.

Fresnoza-Flot's study on Filipino women in transnational relationships and divorce also shows that some of the mothers she interviewed in Belgium were reluctant to use state institutions to claim child maintenance and other financial benefits from their former partner. These mothers described negative social images in Belgium on Filipino women as being in relationships only for economic purposes or even being "bought" by their Belgian husbands. To counter such images, these mothers refused to start court procedures to claim the financial benefits they were entitled to, opting instead to work more and make ends meet to maintain their children themselves. Fresnoza-Flot did not encounter these arguments with interviewees living in the Netherlands. Rather, when some Filipino mothers in the Netherlands were reluctant to claim child maintenance, Dutch social workers urged them to make these claims, in the best interest of their children.

\section{Aims of the special issue}

This special issue aims to investigate interactions of minority families with law and state institutions from a socio-legal perspective, with a particular focus on issues relating to children. Thus far, different aspects of minority families' interactions with law and state institutions tend to be studied in different academic fields, which hardly ever meet. For example, studies on structural inequalities in the outcomes of decision-making in child protective services or the youth criminal system regarding with minority children are largely disconnected from studies of courts and state institutions dealing with claims made by migrant and religious minorities. Similarly, studies on minority language or religious education, on migrant parents' interactions with parenting services in big cities, or transnational families, all take place in different disciplines. This special issue aims to overcome such disciplinary limitations by including contributions from different disciplinary and national backgrounds, including law; migration, diaspora, and transnational families; sociology; socio-legal studies; anthropology; and gender and ethnicity studies.

Furthermore, the special issue aims to examine intersections of religion, ethnicity, and culture to better understand variations in the positioning of various minorities vis-à-vis state actors. How does the positioning of minorities in different European countries influence their experiences with law and state institutions? How does ethnic background or migration/residence status impact on family members' encounters with the state? How do multiple interactions with state institutions shape minority family life?

This special issue draws on case studies from different types of minorities, including migrant and post-colonial but also religious minorities, from a range of different countries, which will give further insights in intersections of ethnicity, culture, nationality, and religion The contributions to this special issue come from different European countries, and focus on different minorities. This rich diversity enables this special issue to compare and analyse encounters of minority families with the state across different contexts. There are contributions on Finland (Mustasaari, Hiitola), Belgium (Fresnoza-Flot), the Netherlands (Fresnoza-Flot, Sportel), and Italy 
(Alqawasmi); on Muslims (Alqawasmi), ISIS-families (Mustasaari), young forced migrants (Hiitola), Filipino mothers (Fresnoza-Flot), and various religious, cultural, and ethnic minorities (Sportel). The authors also approach the topic from different angles: public and political debates (Mustasaari), Imams and religious centres (Alqawasmi), courts (Sportel), and people getting into contact with these institutions (Fresnoza-Flot, Hiitola, Alqawasmi).

\section{References}

Abrego, L.J., 2011. Legal consciousness of undocumented Latinos: Fear and stigma as barriers to claims-making for first-and 1.5-generation immigrants. Law $\mathcal{E}$ Society Review, 45(2), 337-370.

Akhtar, R.C., 2013. British muslims and transformative processes of the Islamic legal traditions: Negotiating law, culture and religion with specific reference to Islamic family law and faith based alternative dispute resolution. PhD Thesis. University of Warwick.

Alqawasmi, A.Y.O., 2021. Marriage and divorce practices in Islamic centers in Italy. Oñati Socio-Legal Series [online], 11(4-this issue). Available from: https://doi.org/10.35295/osls.iisl/0000-0000-0000-1198 [Access 15 July 2021].

Al-Sharmani, M., 2017. Divorce among Transnational Finnish Somalis: Gender, Religion, and Agency. Religion and Gender [online], 7, 70-87. Available from: https://doi.org/10.18352/rg.10207 [Access 15 July 2021].

Andrikopoulos, A., 2021. Love, money and papers in the affective circuits of crossborder marriages: beyond the "sham"/"genuine" dichotomy. Journal of Ethnic and Migration Studies [online], 47(2), 1-18. https://doi.org/10.1080/1369183X.2019.1625129 [Access 15 July 2021].

Bakker, L.G.H., et al., 2010. Sharia in Nederland. Een studie naar islamitische advisering en geschilbeslechting bij moslims in Nederland [online]. Nijmegen: Radboud Universiteit Nijmegen, Instituut voor Culturele Antropologie en Ontwikkelingsstudies/Radboud Universiteit Nijmegen, Instituut voor Rechtssociologie/WODC. Available from: https://repository.ubn.ru.nl/bitstream/handle/2066/90171/90171.pdf?sequence $=1 \&$ isAllowed $=y$ [Access 15 July 2021].

Bano, S., 2007. Islamic Family Arbitration, Justice and Human Rights in Britain. Law, Social Justice \& Global Development [online]. Available from: https://warwick.ac.uk/fac/soc/law/elj/lgd/2007 1/bano [Access 15 July 2021].

Bano, S., 2012. Muslim Women, Divorce and Shari'ah Councils in Brittain. In: R. Mehdi, W. Menski and J.S. Nielsen, eds., Interpreting divorce law in Islam. Copenhagen: DJØF.

Blom, N., Huijts, T., and Kraaykamp, G., 2016. Ethnic health inequalities in Europe. The moderating and amplifying role of healthcare system characteristics. Social Science $\mathcal{E}$ Medicine, 158, 43-51.

Bowen, J.R., 2016. On British Islam: Religion, Law, and Everyday Practice in Shari 'a Councils. Princeton University Press. 
Charsley, K., 2005. Vulnerable Brides and Transnational Ghar Damads: Gender, Risk and 'Adjustment' among Pakistani Marriage Migrants to Britain. Indian Journal of Gender Studies, 12(2-3), 381-406.

Coutin, S.B., 2003. Legalizing moves: Salvadoran immigrants' struggle for US residency. Ann Arbor: University of Michigan Press.

de Hart, B., and Besselsen, E., 2021. "Everything went according to the rules". Female citizen sponsors' legal consciousness, intimate citizenship and family migration law. Identities [online], 28(1), 37-55. Available from: https://doi.org/10.1080/1070289X.2020.1723310 [Access 15 July 2021].

Feldman-Savelsberg, P., 2016. Mothers on the Move. University of Chicago Press.

Feldman-Savelsberg, P., 2017. Mothers on the move: Reproducing belonging between Africa and Europe. University of Chicago Press.

Fresnoza-Flot, A., 2021. The best interests of the child in "mixed" couples' divorce in Belgium and the Netherlands: Filipino mothers' socio-legal encounters about their children. Oñati Socio-Legal Series [online], 11(4-this issue). Available from: https://doi.org/10.35295/osls.iisl/0000-0000-0000-1180 [Access 15 July 2021].

Gleeson, S., 2010. Labor Rights for All? The Role of Undocumented Immigrant Status for Worker Claims Making. Law \& Social Inquiry [online], 35(3), 561-602. Available from: https://doi.org/10.1111/j.1747-4469.2010.01196.x [Access 15 July 2021].

Griffiths, M., 2021. “My passport is just my way out of here". Mixed-immigration status families, immigration enforcement and the citizenship implications. Identities [online], 28(1), 1-19. Available from: https://doi.org/10.1080/1070289X.2019.1625568 [Access 15 July 2021].

Hiitola, J., 2021. Family separation and everyday (in)security in the lives of unaccompanied refugee minors. Oñati Socio-Legal Series [online], 11(4-this issue). Available from: https://doi.org/10.35295/osls.iisl/0000-0000-0000-1202 [Access 15 July 2021].

Jaraba, M., 2020. Khul' in Action: How Do Local Muslim Communities in Germany Dissolve an Islamic Religious-Only Marriage? Journal of Muslim Minority Affairs [online], 40(1), 26-47. Available from: https://doi.org/10.1080/13602004.2020.1737414 [Access 15 July 2021].

Jones, J., 2020. Muslim Alternative Dispute Resolution: Tracing the Pathways of Islamic Legal Practice between South Asia and Contemporary Britain. Journal of Muslim Minority Affairs [online], 40(1), 48-66. Available from: https://doi.org/10.1080/13602004.2020.1741170 [Access 15 July 2021].

Jones, J., and Shanneik, Y., 2020. Reformulating Muslim Matrimony: Islamic Marriage and Divorce in the Contemporary United Kingdom and Europe. Journal of Muslim Minority Affairs [online], 40(1), 1-5. Available from: https://doi.org/10.1080/13602004.2020.1744841 [Access 15 July 2021].

Jones, R., 2012. State Encounters. Environment and Planning D: Society and Space, 30, 805821. 
Keshavjee, M., 2007. Alternative Dispute Resolution in a Diasporic Muslim Community in Britain. In: P. Shah, ed., Law and Ethnic Plurality. Socio-Legal Perspectives. Leiden/Boston: Martinus Nijhoff.

Kubal, A., 2014. Struggles against subjection. Implications of criminalization of migration for migrants' everyday lives in Europe. Crime, Law and Social Change, $62,91-111$.

Leerkes, A., Martinez, R., and Groeneveld, P., 2019. Minority Paradoxes: Ethnic Differences in Self-reported Offending and Official Crime Statistics. The British Journal of Criminology, 59(1), 166-187.

Malheiros, J., 2002. Ethni-cities: residential patterns in the Northern European and Mediterranean metropolises - implications for policy design. International Journal of Population Geography [online], 8(2), 107-134. https://doi.org/10.1002/ijpg.247 [Access 15 July 2021].

Menjívar, C., and Lakhani, S.M., 2016. Transformative effects of immigration law: Immigrants' personal and social metamorphoses through regularization. American Journal of Sociology [online], 121(6), 1818-1855. Available from: https://doi.org/10.1086/685103 [Access 15 July 2021].

Mustasaari, S., 2021. Affective constructions of justice: ISIS-families and the law in the Finnish public debate. Oñati Socio-Legal Series [online], 11(4-this issue). Available from: https://doi.org/10.35295/osls.iisl/0000-0000-0000-1159 [Access 15 July 2021].

Petintseva, O., 2018. Youth justice and migration: Discursive harms. New York: Springer.

Ragazzi, F., 2016. Countering terrorism and radicalisation: Securitising social policy? Critical Social Policy, 37(2), 163-179.

Rohe, M., 2018. Alternative Dispute Resolution among Muslims in Germany and the Debate on "Parallel Justice". In: N.V. Vinding, E. Racius and J. Thielmann, eds., Exploring the Multitude of Muslims in Europe. Leiden/Boston: Brill.

Rohe, M., and Jaraba, M., 2015. Paralleljustiz. Berlin: Senatsverwaltung für Justiz und Verbraucherschutz.

Sarat, A., 1990. The law is all over: power, resistance and the legal consciousness of the welfare poor. Yale Journal of Law \& the Humanities, 2, 343.

Shinozaki, K., 2015. Migrant citizenship from below: Family, domestic work, and social activism in irregular migration. New York: Palgrave Macmillan.

Siddiqui, M., et al., 2018. The independent review into the application of sharia law in England and Wales. London: Presented to Parliament by the Secretary of State for the Home Department by Command of Her Majesty.

Sportel, I., 2016. Divorce in Transnational Families. Marriage, Migration and Family Law. London: Palgrave Macmillan.

Sportel, I., 2021. Claims-making in court cases on children: Religion, ethnicity, and culture in cases of Dutch minority families against the state. Oñati Socio-Legal Series [online], 11(4-this issue). Available from: https://doi.org/10.35295/osls.iisl/0000-0000-0000-1209 [Access 15 July 2021]. 
Sportel, I., Hart, B.D., and Kulk, F., 2019. Transnational Families Navigating the Law: Marriage, Divorce and Wellbeing. In: M. Tiilikainen, M. Al-Sharmani and S. Mustasaari, eds., Wellbeing of Transnational Muslim Families: Marriage, Law and Gender. London: Routledge.

Tas, L., 2013. Resolving Family Disputes in the Gurbet: The Role of Kurdish Peace Committee and Roj Women. Oñati Socio-Legal Series [online], 3(6), 1111-1135. Available from: https://www.opo.iisj.net/index.php/osls/article/view/237/0 [Access 15 July 2021].

van Rossum, W.M., 1999. Winnende onderzoeksprojecten: Culturele minderheden en eigen vormen van rechtspleging; een rechtsantropologisch onderzoek naar het rechtspreken van alevitische Turken. Recht der Werkelijkheid, 2, 102-109.

Vinnerljung, B., et al., 2008. Out-of-home care among immigrant children in Sweden: a national cohort study. International Journal of Social Welfare, 17(4), 301-311.

Walker, G., 2008. Overrepresented Minorities in Special Education in the United States and Romania: Comparison between African-American and Roma Populations in Disability Studies. Research in Comparative and International Education, 3(4), 394403.

Webster, C., 2018. "Race", ethnicity, social class and juvenile justice in Europe. In: B. Goldson, ed., Juvenile Justice in Europe. London: Routledge.

Yuval-Davis, N., Wemyss, G., and Cassidy, K., 2019. Bordering. Hoboken: John Wiley \& Sons.

Zivi, K., 2011. Making rights claims: A practice of democratic citizenship. Oxford University Press. 